\title{
Üniversite Öğrencilerinin Spora Yönelik Tutumlarinin Yaşam Kalitesi, Düzeylerine Etkisinin İncelenmesi: Doğu Marmara Bölgesi Üniversiteleri Örneği
}

DOI: 10.26466/opus.665339

\author{
Ülkü Çoban*- Betül Bayaz1t** - Merve Uca *** \\ ${ }^{*}$ Dr. Öğr. Üyesi. Yalova Üniversitesi Spor Bilimleri Fakültesi, Yalova / Türkiye \\ E-Posta: ulku.coban@yalova.edu.tr \\ ORCID: $\underline{0000-0001-8308-7655}$ \\ **Doç.Dr. Kocaeli Üniversitesi, Spor Bilimleri Fakültesi, İzmit/Kocaeli/Türkiye \\ E-Posta: betul.bayazit@kocaeli.edu.tr \\ ORCID: 0000-0003-3547-2035 \\ ***Dr. Öğr. Üyesi. İstanbul Aydın Üniversitesi, Spor Bilimleri Fakültesi, İstanbul/Türkiye \\ E-Posta: $\underline{\text { merveuca@aydin.edu.tr }}$ \\ ORCID: $\underline{0000-0003-3325-8828}$

\section{Öz}

Bu araştırmada; Doğu Marmara Bölgesi Üniversitelerinde (Kocaeli Üniversitesi, Düzce Üniversitesi, Sakarya Üniversitesi, Bolu Abant İzzet Baysal Üniversitesi, Yalova Üniversitesi) farklı programlarda öğrenim gören öğrencilerin spora yönelik tutumlarmın yaşam kalitesi düzeyine etkisinin incelenmesi amaçlanmıştır. Araştırma, Doğu Marmara bölgesinde yer alan 5 Devlet üniversitesinin farklı bölümlerinde öğrenim görmekte olan toplam 933 lisans ve ön lisans öğrencileri üzerinde gerçekleştirilmiştir. Araştırma örneklemin de, çalışma grubunu oluşturan üniversite öğrencilerinin spora yönelik tutumlarının yaşam kalitesine etkisi incelenmiştir. Çalışma verileri değerlendirilirken tanımlayıcı istatistiksel metodları (Sayı, Yüzde, Aritmetik Ortalama, Standart sapma) kullanlmıştır. "t-testi", ANOVA, "Post-Hoc" "Tukey" ve "Dunnett T3" testi uygulanmıştır. Verilerin çözümlemesi SPSS 20.0 paket programında yapılmıştır. Verilerin analizi \%95 güven aralığında, $p<0.05$ anlamlılık düzeyinde değerlendirilmiştir. Çalışma grubunun eğitim aldığı üniversite, eğitim düzeyi, cinsiyet, yaş, sportif tutum, yaşam kalitesi, puan ortalamaları, her ne kadar istatistiksel açıdan anlamlı bir fark olmasa da, hemen hemen tüm parametrelerde $(p<0,05)$ düzeyde pozitif yönde ve anlaml bir ilişkiye sahip olduğu bulunmuştur. Sportif tutumun yaşam kalitesini pozitif yönde anlaml düzeyde $(p<0,05)$ açıkladığını göstermektedir.

Anahtar Kelimeler: Üniversite öğrencisi, Spora Yönelik Tutum, Yaşam Kalitesi 


\title{
Analyzing the Effect of University Students' Attitudes towards Sports on Quality of Life:Eastern Marmara Region Universities Sample
}

\begin{abstract}
In this study; The aim of this study is to determine the effects of attitudes of students studying in differen tprograms in East Marmara Region Universities (Kocaeli University, Düzce University, Sakarya University, Abant İzet Baysal University, Yalova University) on their quality of life. This research was carried out on 933 undergraduate and associate students studying in different departments of 5 foundation universities in East Marmara region. Theeffect of attitudes of the university students, who constitute sportive attitude the study group, on the quality of life, werein vestigated. In the research sample, the effect of the attitudes of the university students, who form the study group, on their quality of life and their levels were examined. Descriptive statistical methods (Number, Percentage, Arithmetic Mean, Standard deviation) were used in the evaluation of the study data. "T-test", ANOVA, "Post-Hoc" uk Tukey "and" Dunnett T3 "test were applied. Data analysis was performed in SPSS 20.0 package program. Data analysis was evaluated at $95 \%$ confidence interval and $p<0.05$ significance level. First of all the sample group, education level, gender, age, sportive attitude, quality of life were not statistically signifi cant. It was found that it had a positive and signifi cant relation ship in al mostall parameters ( $p$ $<0.05)$. It shows that sportive attitude explains the quality of life positively and significantly $(p<0.05)$.
\end{abstract}

Keywords: University Student, AttitudeTowards Sports, Quality Of Life 


\section{Giriş}

Spor fert ve toplum ilişkilerini geliştirdiği gibi, toplumun yüceltilmesinde önemli bir araçtır. Gelişmiş toplumlar, sporu en önemli propaganda aracı olarak kabul etmişler ve diş ülkelerde kendilerini temsil edecek gençlerin en iyi şekilde yetiştirilmesi gereğine inanmışlardır (Yetim. 2016). Tutum (attitude) kavramı ise psikolojinin önemli bir kavramıdır. Kelime anlamı olarak tutumun, iyi-kötü, zararlı-faydalı, hoş-nahoş ve olağan-olağandışı gibi öz-nitelik boyutlarında psikolojik bir nesnenin değerlendirmesini temsil ettiği konusunda genel bir fikir birliği vardır (Ajzen 2001).

Bir başka deyişle tutum, bireyin karşılaştı̆̆ çıan bir uyaran (nesne, durum, olay) karşısında onunla ilgili olumlu veya olumsuz değerlendirme yapmasıdır. Tutumlar, bilişsel, etkisel ve davranışsal olmak üzere üç grupta incelenir. Bilişsel tutum düşünceleri, etkisel tutum duyguları ve davranışsal tutumlar davranışları kapsamaktadır (Gerrig ve diğ. 2013) Üniversite öğrencilerinin kültürel ve sosyal normların oluşumundaki rolleri göz önüne alınd1ğında bu öğrencilerin sahip oldukları sportif aktivite alışkanlıklarının önemi artmaktadır. Düzenli olarak yapılan spor aktivitelerinin sağlık üzerindeki etkileri kabul edilmekle birlikte yaşam kalitesi ile arasındaki ilişki net bir şekilde açıklanamamıştır. Genel olarak spora yönelik tutum ile yaşam kalitesi, düzeylerine ilişkin yeteri kadar araştırma yapılmadığı görülmüştür. Sportif aktivitelerin çocuk ve genç bireylerin iletişim becerilerinin güçlenmesinde ve sosyalleşmesinde en önemli araçlardan biri olduğu açıktır. Sporun bireyin kişilik gelişiminde ve topluma adaptasyon sürecinde etkili olduğunu ortaya koyan bulgular elde edildiği gibi olumsuz bazı etkiler yarattığı da araştırmalarda ortaya konulmuştur.

Üniversite öğrencilerinin spora yönelik tutumlarının yaşam kalitesi ile arasında bir ilişki olduğu ve spora yönelik tutumun öz yeterlilik duygularını arttırarak yaşam kalitesinde de pozitif yönde bir etki yarattı̆̆ düşünülmektedir. Bununla beraber, sporla uğraşan birey sayısını arttırarak spor toplumu oluşturmak için yapılan tüm çalışmaların temel hedeflerine bakmak gerekmektedir. Bu şekilde cinsiyet farkı olup olmadığı, spor etkinliklerine ne kadar eğilimli oldukları, sportif bakış açıları, sporsal alışkanlıkları, spor etkinlikleri ile kişiliklerini nasıl terbiye edebildikleri gibi temel konuların, geleceğimize ışık tutacak üniversite öğrencileri üzerinde çalışılması ihtiyacını doğurmaktadir. 
Alan yazın incelendiğinde üniversite öğrencilerinin spora yönelik tutumları ile ilgili çalışma bulmakta güçlük çekilirken; ilkokul, ortaokul ve lise öğrencilerinin beden eğitimi ve spor dersine ilişkin tutumlarını incelemiş olan çalışmalar bulunabilmektedir (Güllü 2009, Çetin 2007, Taşğın ve Tekin 2009, Şişko ve Demirhan 2002). Literatürdeki bu eksikliğin giderebilmesi adına; bu araştırmada, spor dişındaki alanlarda eğitim gören üniversite öğrencilerinin spora yönelik tutumlarının, Yaşam Kalitesi düzeylerine etkisinin belirlenmesi amaçlanmıştır.

\section{Yöntem}

\section{Araştırmanın Modeli}

Bu araştırma "tarama modeli" olarak tasarlanmıştır. "Tarama modelleri, geçmişte ya da halen var olan bir durumu var olduğu şekilde betimlemeyi amaçlayan araştırma yaklaşımlarıdır. Araştırmaya konu olan olay, birey ya da nesne, kendi koşulları içinde ve olduğu gibi tanımlanmaya çalışılır. Onları herhangi bir şekilde değiştirme, etkileme çabası gösterilmez" (Karasar, 2009,). Araştırmada öğrencilerin spora yönelik tutumlarının yaşam kalitesi, düzeylerine belirleyici etkileri ortaya konulacaktır. Araştırmanın bağımsız değişkenini spora yönelik tutum; bağımlı değişkeni ise yaşam kalitesi, oluşturmaktadır. Bu çalışma Kocaeli Üniversitesi Girişimsel Olmayan Klinik Araştırmalar Etik kurulunun 19.07.2017 tarihli kararı ve KÜ GOKAEK 2017/10.15 no'lu raporu ile araştırmanın amacı, hedefleri ve yöntemi gönüllüler açısından beklenen yarar ve riskler dikkate alınarak değerlendirilerek ve araştırmanın ilgili protokol doğrultusunda belirtilen merkezlerde yürütülmesi etik açısından uygun bulunmuştur.

\section{Evren ve Örneklem}

Çalışmanın evrenini Doğu Marmara bölgesindeki beş devlet üniversitesin de öğrenim gören öğrenciler oluşturmaktadır. Doğu Marmara bölgesinde devlet üniversitesi olarak Kocaeli Üniversitesi toplam öğrenci sayıs1 81.000 üzeri; Düzce Üniversitesi toplam öğrenci sayısı 29.477; Sakarya Üniversitesi toplam öğrenci sayısı 93.464; Yalova Üniversitesi toplam öğrenci sayısı 14.816; Abant 
İzzet Baysal Üniversitesi toplam öğrenci sayısı 32.906; dır. Örneklemi Doğu Marmara bölgesinde yer alan beş üniversiteden 933 öğrenci oluşturmaktadır.

\section{Veri Toplama Araçları}

Araştırmada veri toplama aracı olarak kişisel bilgi formu, spora yönelik tutum ölçeği, yaşam kalitesi ölçeği, uygulanmıştır. Araştırmada kullanılan "Spora Yönelik Tutum Ölçeği (SYTÖ)" Şentürk (2014) tarafından geliştirilmiştir. Toplam 25 madde ve 3 alt boyuttan (spora ilgi duyma, sporla yaşama ve aktif spor yapma) oluşmaktadır. SYTÖ 5'li likert tipi “Tamamen Katilıyorum (5), Katılıyorum (4), Kararsızım (3), Katılmıyorum (2), Kesinlikle Katılmıyorum (1)" şeklinde derecelendirilmektedir. Ölçekten alınabilecek minimum puan 25 ve maksimum puan $125^{\prime}$ tir. Puanın yüksekliği, spora yönelik tutumun yüksekliğine işaret etmektedir.

Çalışmada yaşam kalitesini belirlemek için Dünya Sağlık Örgütü tarafından, 15 işbirliği merkezinin katılımıyla hazırladığı 27 soruluk WHOQOLBREF (dünya sağlık örgütü yaşam kalitesi ölçeği kısa form) ölçeğinin Türkçe versiyonu uygulanmıştır. Anket, kişinin kendi yaşam kalitesini puanlaması mantığına dayanmaktadır. WHOQOL (100 soru) ve WHOQOL-BREF (26 soru) olmak üzere, tam ve kısaltılmış şekilde iki formu vardır (Başaran, Güzel ve Sapel 2005). WHOQOL-BREF ölçeği; bedensel alan, psikolojik alan, sosyal ilişkiler ve çevre olmak üzere dört alt alandan oluşmaktadır. Likert tipi bir ölçektir. Farklı kültürlerde saha çalışmaları yapılmış olan ölçek, erişkin yaş grubuna uygulanabilmekte ve yaşam kalitesinin güvenilir ve geçerli bir ölçüm aracı olarak kabul edilmektedir (Fidaner ve diğ. 1999). Orijinal versiyonu 26 maddeden oluşan ölçeğin, Türkçe versiyonu 27 maddeden oluşmaktadır. Fidaner ve diğ. tarafından Türkçeye uyarlanmıştır.

\section{Verilerin İstatistiksel Analizi}

Çalışmada elde edilen bulgular değerlendirilirken, istatistiksel analizler için SPSS (Statistical Pack age for Social Sciences) for Windows 20.0 programı kullanılmıştır. Çalışma verileri değerlendirilirken tanımlayıcı istatistiksel metotları (Sayı, Yüzde, Aritmetik Ortalama, Standart sapma) kullanılmıştır. Hipotez testleri olarak; iki bağımsız örneklem grubu ortalamaları açısından farklı 
olup olmadığını anlamak için "t-testi", grup sayısının ikiden fazla olduğu durumlarda ise "ANOVA" kullanılmıştır. ANOVA testinde farklılığın hangi gruplar arasında olduğunu ortaya koymak üzere "Post-Hoc" testlerinden varyans eşitliği durumuna göre "Tukey" veya "Dunnett T3" testleri uygulanmıştır. Bağımlı değişkenin bağımsız değişken ile arasındaki ilişkiyi, ilişkinin şiddeti ve yönü açısından analizlemek için bu çalışmada "Regresyon Analizi" yapılmıştır. Sonuçlar $\% 95$ güven aralığında, anlamlılık $\mathrm{p}<0,05$ düzeyinde değerlendirilmiştir. Bu amaç doğrultusunda şu sorulara yanıt aranmaya çalışılmıştır; Doğu Marmara Bölgesi Üniversitelerinin farklı programlarında öğrenim gören öğrencilerde; Spora yönelik tutum yaşam kalitesine nasıl bir etki yaratmıştır. Araştırma 2017-2018 eğitim-öğretim yılında farklı programlarda öğrenim gören 386's1 erkek 547'si kadın olmak üzere toplam 933 gönüllü öğrenci ile sınırlandırılmıştır.

\section{Bulgular}

\section{Tanımlayıcı İstatistiklere (Ölçütlere) İlişkin Bulgular}

Tablo 1. Örneklem Grubunun Yaşlarna İlişkin Bulgular

\begin{tabular}{lll}
\hline Yaş Grubu & Frekans & Yüzde (\%) \\
\hline 18 yaş ve altı & 55 & 5,9 \\
\hline 19 yaş & 145 & 15,5 \\
\hline 20 yaş & 200 & 21,4 \\
\hline 21 yaş & 190 & 20,4 \\
\hline 22 yaş & 150 & 16,1 \\
\hline 23 yaş ve üzeri & 193 & 20,7 \\
\hline Toplam & $\mathbf{9 3 3}$ & $\mathbf{1 0 0 , 0}$ \\
\hline
\end{tabular}

Örneklem grubunun yaşlarına göre dağılımı tablo.1'de incelenmiştir. Buna göre araştırmaya katılan öğrencilerin 4'nün $(\% 0,4) 17,49$ 'unun $(\% 5,3)$ 18,145'inin (\%15,5) 19,200'ünün (\%21,4) 20, 190'1nın (\%20,4) 21, 150'sinin $(\% 16,1) 22,83^{\prime}$ ünün $(\% 8,9)$ 23, 56'sının (\% 6) 24, 31'inin (\%3,3) 25 yaşında ve 23 'ünün $(\% 2,5) 26$ yaş ve üzeri olduğu görülmektedir. 
Tablo 2. Örneklem Grubunun Spor Yaptı̆̆ı Sürelere İlişkin Bulgular

\begin{tabular}{lll}
\hline Spor Yaptıkları Yıl & Frekans & Yüzde \\
\hline Hiç & 313 & 33,5 \\
\hline 1 yll & 240 & 25,7 \\
\hline 2 yll & 90 & 9,6 \\
\hline 3 yll & 50 & 5,4 \\
\hline 4 yll & 44 & 4,7 \\
\hline 5 yll ve üzeri & 196 & 21,0 \\
\hline Toplam & $\mathbf{9 3 3}$ & $\mathbf{1 0 0 , 0}$ \\
\hline
\end{tabular}

Örneklem grubunun spor yaptığı sürelere göre dağılımı tablo 2'de incelenmiştir. Buna göre araştırmaya katılan öğrencilerin 313'ü $(\% 33,5)$ hiç spor yapmamıştır. Örneklem grubunun 240'1 (\%25,7) 1 yıl, 90'1 (\%9,6) 2 yıl, 50'si $(\% 5,4) 3$ yıl, 44'ü (\%4,7) 4 yıl, 47'si (\%5) 5yıl, 29'u (\%3,1) 6yıl,18'i (\%1,9) 7yıl, 20 'si (\%2,1) 8yıl,14'ü (\%1,5) 9yıl, 40’1 (\%4,3) 10 yıl, 29'u (\%3,0) ise 11 yll ve 11 yıldan daha uzun süre ile spor yapmıştır. Örneklemimizde en uzun spor yapan 20 yıl ise 1 kişidir, onu takip eden 17 ve 16 yıl ile yine 1'er kişidir.

Tablo 3. Örneklem Grubunun Cinsiyetlerine İlişkin Bulgular

\begin{tabular}{lll}
\hline Cinsiyet & Frekans & Yüzde (\%) \\
\hline Erkek & 386 & 41,4 \\
\hline Kadın & 547 & 58,6 \\
\hline Toplam & $\mathbf{9 3 3}$ & $\mathbf{1 0 0 , 0}$ \\
\hline
\end{tabular}

Örneklem grubunun cinsiyetlerine göre dağglımı tablo 3 'te incelenmiştir. Buna göre araştırmaya katılan öğrencilerin 386'sı (\% 41,4) erkek, 547'si (\% 58,6) kadındır.

Tablo 4. Örneklem Grubunun Medeni Durumlarna İlişkin Bulgular

\begin{tabular}{lll}
\hline Medeni Durum & Frekans & Yüzde (\%) \\
\hline Evli & 22 & 2,4 \\
\hline Bekâr & 910 & 97,6 \\
\hline Toplam & 932 & 100,0 \\
\hline
\end{tabular}

Örneklem grubunun medeni durumlarına göre dağılımı tablo 4'de incelenmiştir. Buna göre araştırmaya katılan öğrencilerin 22'si (\% 2,4) evli, 910'u ise $(\% 97,6)$ bekârdır. 
Tablo 5. Örneklem Grubunun Okuduğu Üniversiteye İlişkin Bulgular

\begin{tabular}{lll}
\hline Üniversite & Frekans & Yüzde (\%) \\
\hline Bolu & 201 & 21,5 \\
\hline Düzce & 140 & 15,0 \\
\hline Kocaeli & 182 & 19,5 \\
\hline Sakarya & 118 & 12,6 \\
\hline Yalova & 292 & 31,3 \\
\hline Toplam & 933 & 100,0 \\
\hline
\end{tabular}

Örneklem grubunun okumakta olduğu üniversitelere göre dağılımı tablo 5 'te incelenmiştir. Buna göre araştırmaya katılan öğrencilerin 201'i (\% 21,5) Bolu Üniversitesi'nde, 140'1 (\%15) Düzce Üniversitesi'nde, 182' si (\% 19,5) Kocaeli Üniversitesi'nde, 118'i (\% 12,6) Sakarya Üniversitesi'nde, 292'si (\% 31,3) Yalova Üniversitesi'nde eğitim yaşantılarına devam etmektedir.

Tablo 6.Örneklem Grubunun Ĕ̆itim Düzeyine İlişkin Bulgular

\begin{tabular}{lll}
\hline Eğitim Düzeyi & Frekans & Yüzde (\%) \\
\hline Önlisans & 34 & 3,7 \\
\hline Lisans & 887 & 95,4 \\
\hline Yüksek Lisans & 9 & 1,0 \\
\hline Toplam & $\mathbf{9 3 0}$ & $\mathbf{1 0 0 , 0}$ \\
\hline
\end{tabular}

Örneklem grubunun öğrenim görmekte olduğu eğitim düzeylerine göre dağılımı tablo.6'da incelenmiştir. Buna göre araştırmaya katılan öğrencilerin $34^{\prime}$ ü $(\% 3,7)$ ön lisans düzeyinde, 887'si (\%95,4) lisans düzeyinde, 9'u (\% 1) yüksek lisans düzeyinde öğrenim görmektedir.

Tablo 7. Örneklem Grubunun Kendilerinin ve Ailelerinin Ekonomik Gelir Dïzeylerine İlişkin Bulgular

\begin{tabular}{lll}
\hline Gelir Düzeyi & Frekans & Yüzde (\%) \\
\hline $0-500$ TL (en düşük) & 36 & 3,9 \\
\hline $501-1500$ TL(düşük) & 185 & 19,9 \\
\hline 1501-2500 TL(orta) & 360 & 38,7 \\
\hline 2501-5000 TL(yüksek) & 277 & 29,8 \\
\hline 5001 TL ve üstü(en yüksek) & 73 & 7,8 \\
\hline Toplam & $\mathbf{9 3 1}$ & $\mathbf{1 0 0 , 0}$ \\
\hline
\end{tabular}

Örneklem grubunun kendilerinin ve ailelerinin ekonomik gelir düzeylerine göre dağılımı tablo 7.'de incelenmiştir. Buna göre araştırmaya katılan öğrencilerin 3'ünün $(\%$ 3,9) ekonomik düzeylerinin 0-500 TL (en düşük), 
185'inin (\% 19,9) 501-1500 TL (düşük), 360'inın (\% 38,7) 1501-2500 TL (orta), 277'sinin (\% 29,8) 2501-5000 TL (yüksek), 73'ünün (\% 7,8) 5001 TL ve üstü ekonomik düzeye sahip oldukları görülmektedir.

Örneklem grubunun genel olarak kendi ekonomik gelir düzeyinden memnun olma durumlarına göre dağılımı tablo 8'de incelenmiştir. Buna göre araştırmaya katılan öğrencilerin 61'inin $(\%$ 6,6) hiç memnun olmadığı, 115 'inin (\% 12,4) memnun olmadığı, 326'sının (\% 35) kısmen memnun olduğu, 386'sının (\% 41,5) memnun olduğu, 43'ünün (\% 4,6) çok memnun olduğu görülmektedir.

Tablo 8. Örneklem Grubunun Genel Olarak Kendi Ekonomik Gelir Düzeyinden Memnun Olma Durumlarna İlişkin Bulgular

\begin{tabular}{lll}
\hline Memnuniyet & Frekans & Yüzde $(\%)$ \\
\hline Hiç değil & 61 & 6,6 \\
\hline Değil & 115 & 12,4 \\
\hline Kısmen memnun & 326 & 35,0 \\
\hline Memnun & 386 & 41,5 \\
\hline Çok memnun & 43 & 4,6 \\
\hline Toplam & $\mathbf{9 3 1}$ & 100,0 \\
\hline
\end{tabular}

Tablo 9. Örneklem Grubunun Gelir Getirici Bir İş Olarak Sporu Yeterli Görme Durumlarna İlişkin Bulgular

\begin{tabular}{lll}
\hline & Frekans & Yüzde (\%) \\
\hline Hiç değil & 122 & 13,1 \\
\hline Değil & 270 & 29,0 \\
\hline Kısmen yeterli & 353 & 37,9 \\
\hline Yeterli & 156 & 16,7 \\
\hline Çok Yeterli & 31 & 3,3 \\
\hline Toplam & $\mathbf{9 3 2}$ & $\mathbf{1 0 0 , 0}$ \\
\hline
\end{tabular}

Örneklem grubunun gelir getirici bir iş olarak sporu yeterli görme durumlarına göre dağılımı tablo 9 da incelenmiştir. Buna göre araştırmaya katılan öğrencilerin 112'sinin (\% 13,1) hiç yeterli görmediği, 270'inin (\% 29) yeterli görmediği, 353'ünün (\% 37,9) kısmen yeterli gördüğü, 156'sının (\% 16,7) yeterli gördüğü, 31'inin çok yeterli gördüğü görülmektedir.

Örneklem grubunun başarı düzeylerine göre dağılımı tablo 10'da incelenmiştir. Buna göre araştırmaya katılan öğrencilerin 65'inin (\% 7) Başarısız Öğrenci, 547'sinin (\% 58,6) Başarılı Öğrenci, 216'sının (\% 23,2) Onur Öğrencisi, 105 'inin (\% 11,3) Yüksek Onur Öğrencisi olduğu görülmektedir. 
Tablo 10. Örneklem Grubunun Başarı Düzeylerine İlişkin Bulgular

\begin{tabular}{lll}
\hline Başarı Düzeyi & Frekans & Yüzde (\%) \\
\hline Başarısı̈ Öğrenci & 65 & 7,0 \\
\hline Başarlı Öğrenci & 547 & 58,6 \\
\hline Onur Öğrencisi & 216 & 23,2 \\
\hline Yüksek Onur Öğrencisi & 105 & 11,3 \\
\hline Toplam & $\mathbf{9 3 3}$ & $\mathbf{1 0 0}$ \\
\hline
\end{tabular}

Tablo 11. Örneklem Grubunun Sportif Tutumları, Yaşam Kaliteleri ve Alt Boyutlarn, Puanlarna İlişkin Bulgular

\begin{tabular}{llllll}
\hline & $\mathrm{N}$ & Minimum & Maksimum & Ortalama & Std. Sapma \\
\hline Sportif Tutum & 933 & 1,84 & 4,96 & 3,076 & 0,543 \\
\hline Yaşam Kalitesi & 933 & 1,54 & 5,00 & 3,512 & 0,533 \\
\hline Algılanan Yaşam Kalitesi & 933 & 1,00 & 5,00 & 3,284 & 1,133 \\
\hline Algılanan Sağllk Kalitesi & 933 & 1,00 & 5,00 & 3,394 & 1,160 \\
\hline Çevresel Sağllk Boyutu & 933 & 1,25 & 5,00 & 3,553 & 0,589 \\
\hline Ruhsal Sağlık Boyutu & 933 & 1,00 & 5,00 & 3,324 & 0,750 \\
\hline Bedensel Sağlık Boyutu & 933 & 1,20 & 5,00 & 3,652 & 0,693 \\
\hline Sosyal İlişkiler Boyutu & 933 & 1,00 & 5,00 & 3,658 & 0,787 \\
\hline
\end{tabular}

Tablo 11'de görüldüğü gibi öğrencilerin sportif tutum puanları 1,84 ile 4,96 arasında değişmektedir. Sportif tutum puan ortalaması ise 3,076' dır. Yaşam Kalitesi 1,54 ile 5,00 arası değişmekte olup ortalaması ise 3,512'dir. Alg1lanan yaşam kalitesi puanı ise 1-5 arası değişmekte ve 3,284 ortalamaya sahiptir. Algılanan sağlık kalitesi 1-5 arasında değer almış ve ortalaması 3,394'tür. Yaşam kalitesinin alt boyutları çevresel sağlık, ruhsal sağlık, bedensel sağlık ve sosyal ilişkiler boyutu sırası ile 1,25 ile 5 arası, 1 ile 5 arası, 1,20 ile 5 arası ve 1 ile 5 arasında değişmektedir ve ortalamaları ise sırası ile 3,553, $3,324,3,652$ ve $3,658^{\prime}$ dir.

\section{Farklılıkların Analizine İlişkin Bulgular}

Öğrencilerinin spora dair tutumlarının puan ortalamalarının, spor yaptıkları yıl miktarına göre anlamlı düzeyde farklılaşma durumunu ortaya koymak amacıyla tek yönlü varyans analizi (f testi) ile yapılmıştır. Yapılan ANOVA testi sonucu tablo 12 ' de ifade edilmektedir. $\mathrm{F}$ değeri 14,588 bulunmuştur. $\mathrm{Bu}$ sonuç 0,05 düzeyinde anlamlı bir farkın olduğunu ortaya koymuş bulunuyor. Farklılığın kaynağını anlamak test yapmadan önce, varyans eşitliği hipotezi test edilmiştir. Levene testi sonucunda $(p<0,05)$ varyansların eşit olma- 
dığ1 sonucu çıkmıştır. Bu nedenle Post-hoc testlerinden Dunnett T3 testi uygulanmıştır. Bu testin sonucunda, 05 anlamlılık düzeyinde; hiç spor yapmamış olmak ile 1 yıl yapmanın ve de 5 yıl ve üzeri yıl spor yapmanın sportif tutumu farklılaştırdığını görmekteyiz. Aynı şekilde 1 yıl spor yapmış olmak ile 2 yıl ve de 5 yıl ve üzeri spor yapmış olmak sportif tutumu farklılaştırmaktadır. 4 yıl yapmak ile 5 yıl ve üzerinde spor yapmış olmak da, 05 anlamlılık düzeyinde sportif tutumu farklılaştırmaktadır.

Tablo 12. Araştırmaya Katılan Üniversite Öğrencilerinin Sportif Tutumlarnnn Spor Yaptı̆̆ı Süre Değişkenine Göre Farklılaşması

\begin{tabular}{|c|c|c|c|c|c|c|}
\hline \multicolumn{2}{|c|}{ Spor Yaptıkları Yıl } & \multicolumn{2}{|l|}{$\mathbf{N}$} & Ortalama & \multicolumn{2}{|c|}{ Std. Sapma } \\
\hline \multicolumn{2}{|l|}{ Hiç } & \multicolumn{2}{|l|}{313} & 3,04 & \multicolumn{2}{|l|}{0,45} \\
\hline \multicolumn{2}{|l|}{$1 \mathrm{y} 1 \mathrm{l}$} & \multicolumn{2}{|l|}{240} & 2,91 & \multicolumn{2}{|l|}{0,46} \\
\hline \multicolumn{2}{|l|}{$2 \mathrm{y} 1 \mathrm{l}$} & \multicolumn{2}{|l|}{90} & 3,19 & \multicolumn{2}{|l|}{0,60} \\
\hline \multicolumn{2}{|l|}{3 yil } & \multicolumn{2}{|l|}{50} & 3,13 & \multicolumn{2}{|l|}{0,58} \\
\hline \multicolumn{2}{|l|}{$4 \mathrm{y} 1 \mathrm{l}$} & \multicolumn{2}{|l|}{44} & 2,92 & \multicolumn{2}{|l|}{0,52} \\
\hline \multicolumn{2}{|c|}{5 yıl ve üzeri } & \multicolumn{2}{|l|}{196} & 3,31 & \multicolumn{2}{|l|}{0,65} \\
\hline \multicolumn{2}{|l|}{ Toplam } & \multicolumn{2}{|l|}{933} & 3,08 & \multicolumn{2}{|l|}{0,54} \\
\hline & (I) Spor Yapılan Yil & \multicolumn{2}{|c|}{ (J) Spor Yapılan Y11 } & $(1-j)$ & Std. Hata & $\mathrm{p}$ \\
\hline & Hiç & \multicolumn{2}{|l|}{$1 \mathrm{y} 1$} & 0,130 & 0,039 & ,013 \\
\hline & & \multicolumn{2}{|l|}{2 yil } & $-0,150$ & 0,068 & ,349 \\
\hline & & \multicolumn{2}{|l|}{3 yil } & $-0,094$ & 0,086 & ,989 \\
\hline & & \multicolumn{2}{|l|}{4 yil } & 0,119 & 0,083 & ,900 \\
\hline & & \multicolumn{2}{|c|}{5 yıl ve üzeri } & $-0,269$ & 0,053 &, 000 \\
\hline & 1 yıl & \multicolumn{2}{|l|}{$2 \mathrm{yll}$} & $-0,280$ & 0,070 & ,001 \\
\hline & & \multicolumn{2}{|l|}{3 yil } & $-0,225$ & 0,087 & 161 \\
\hline & & 4 yıl & & $-0,011$ & 0,084 & 1,000 \\
\hline & & 5 yıl ve ü & & $-0,399$ & 0,055 &, 000 \\
\hline & 2 yil & 3 yil & & 0,056 & 0,103 & 1,000 \\
\hline & & 4 yıl & & 0,269 & 0,101 & 121 \\
\hline & & 5 yıl ve ü & & $-0,119$ & 0,078 & ,869 \\
\hline & 3 yil & 4 yıl & & 0,214 & 0,113 & 604 \\
\hline Sportif & & $5 \mathrm{yll}$ ve $\ddot{\mathrm{u}}$ & & $-0,174$ & 0,094 & ,629 \\
\hline Tutum & 4 yil & 5 yıl ve $\ddot{u}$ & & $-0,388$ & 0,091 & ,001 \\
\hline & & $\begin{array}{l}\text { Kareler } \\
\text { Toplamı }\end{array}$ & $\begin{array}{l}\text { Serbestlik } \\
\text { Derecesi }\end{array}$ & $\begin{array}{l}\text { Kareler } \\
\text { Ortalamas1 }\end{array}$ & f & $\mathrm{p}$ \\
\hline Sportif & Gruplar arası & 20,078 & 5 & 4,016 & 14,588 &, $000^{*}$ \\
\hline Tutum & Gruplar içi & 255,180 & 927 & 275 & & \\
\hline & Toplam & 275,259 & 932 & & & \\
\hline
\end{tabular}

${ }^{*} p<0,05$ 
Tablo 13. Araştırmaya Katılan Üniversite Öğrencilerinin Sportif Tutumlarının Cinsiyet Değişkenine Göre Farklılaşmasına İlişkin t Testi Bulguları

\begin{tabular}{lllllll}
\hline & Cinsiyet & $\mathrm{n}$ & Ortalama & Std. Sapma & $\mathrm{t}$ & $\mathrm{p}$ \\
\hline \multirow{2}{*}{ Sportif Tutum } & Erkek & 386 & 3,02 & 0,57 & \multirow{2}{*}{$-2,666$} & \multirow{2}{*}{$0,008^{*}$} \\
\cline { 2 - 6 } & Bayan & 547 & 3,12 & 0,52 & & \\
\hline
\end{tabular}

${ }^{*} p<0,05$

Üniversite öğrencilerinin sportif tutum puan ortalamalarının, cinsiyetlerine göre farklılaşma durumunu ortaya koymak amaciyla bağımsız gruplar için $t$ testi kullanılmıştır. Yapılan t testine ilişkin bulgular tablo 13'te verilmiştir. Yapılan Levene testi sonucunda varyansların eşit olduğu sonucu elde edilmiştir $(p>0,05)$. Eşit varyans kabulüne göre baktığımız $t$-testi sonucu ise bize iki grubun birbirinden anlamlı düzeyde farklılaştığını göstermekte$\operatorname{dir}(\mathrm{p}<0,05)$. Yani cinsiyetler arasında sportif tutum açısından istatistiksel açdan anlamlı farklılık bulunmuştur.

Tablo 14. Araştırmaya Katılan Üniversite Öğrencilerin Sportif Tutumlarının Medeni Durumu Değişkenine Göre Farklılaşmasına İlişkin T Testi Bulgulan

\begin{tabular}{lllllll}
\hline & Medeni Durum & $\mathrm{n}$ & Ortalama & Std. Sapma & $\mathrm{t}$ & $\mathrm{p}$ \\
\hline \multirow{2}{*}{ Sportif Tutum } & 1 & 22 & 3,44 & 0,64 & \multirow{2}{*}{0,398} & $0,001^{*}$ \\
\cline { 2 - 6 } & 2 & 910 & 3,07 & 0,54 & & \\
\hline
\end{tabular}

${ }^{*} p<0.05$

Üniversite öğrencilerinin sportif tutum puan ortalamalarının, medeni durumlarına göre anlamlı bir farklılık gösterip göstermediğini ortaya koymak amacıyla bağımsız gruplar için $t$ testi kullanılmıştır. Yapılan $t$ testine ilişkin bulgular tablo 14 'te verilmiştir. Yapılan testte, Levene testi sonucunda varyansların eşit olduğu sonucu elde edilmiştir ( $p>0,05)$. Eşit varyans kabulüne göre baktığımız t-testi sonucu ise bize iki grubun birbirinden anlamlı düzeyde farklılaştığını göstermektedir $(\mathrm{p}<0,05)$. Yani medeni durumun farklı olması sportif tutum açısından farklılık oluşturmuştur.

Tablo 15. Araştırmaya Katılan Üniversite Öğrencilerinin Sportif Tutumlarnın Okuduklarn Üniversite Değişkenine Göre Farkhlaşmasına İlişkin ANOVA Bulguları

\begin{tabular}{|c|c|c|c|c|c|c|}
\hline & & $\begin{array}{l}\text { Kareler } \\
\text { Toplamı }\end{array}$ & $\begin{array}{l}\text { Serbestlik } \\
\text { Derecesi }\end{array}$ & $\begin{array}{l}\text { Kareler } \\
\text { Ortalaması }\end{array}$ & f & $\mathrm{p}$ \\
\hline \multirow{3}{*}{$\begin{array}{l}\text { Sportif } \\
\text { Tutum }\end{array}$} & Gruplar arası & 39,785 & 4 & 9,946 & \multirow{3}{*}{39,199} & \multirow{3}{*}{$0,000^{*}$} \\
\hline & Gruplar içi & 235,473 & 928 & 0,254 & & \\
\hline & Toplam & 275,259 & 932 & & & \\
\hline
\end{tabular}


Tablo 16. Araştırmaya Katılan Üniversite Öğrencilerinin Sportif Tutumlarnıın Okuduklarn Üniversite Değişkenine Göre Farklılaşmanın Anlamlılı̆̆ına İlişkin Çoklu Karşılaştırma Testi (Post Hoc - Dunnett T3 Testi)

\begin{tabular}{clllll}
\hline & (I) Unı & (J) Unı & $(1-j)$ & Std. Hata & $p$ \\
\hline \multirow{4}{*}{ Sportif Tutum } & Düzce & 0,573 & 0,045 & $0,000^{*}$ \\
\cline { 2 - 6 } & Kolu & Kocaeli & 0,178 & 0,050 & $0,004^{*}$ \\
\cline { 2 - 6 } & Sakarya & $-0,142$ & 0,067 & 0,302 \\
\cline { 2 - 6 } & Yalova & 0,154 & 0,048 & $0,014^{*}$ \\
\cline { 2 - 6 } & Düzce & Kocaeli & $-0,395$ & 0,044 & $0,000^{*}$ \\
\cline { 2 - 6 } & & $-0,715$ & 0,063 & $0,000^{*}$ \\
\cline { 2 - 6 } & Sakarya & $-0,420$ & 0,042 & $0,000^{*}$ \\
\cline { 2 - 6 } & Yalova & $-0,320$ & 0,067 & $0,000^{*}$ \\
\cline { 2 - 6 } & Kocaeli & Sakarya & $-0,025$ & 0,047 & 1,000 \\
\cline { 2 - 6 } & Salova & 0,295 & 0,065 & $0,000^{*}$ \\
\hline
\end{tabular}

${ }^{*} p<0.05$

Öğrencilerinin spora dair tutumlarının puan ortalamalarının, okudukları üniversiteye göre anlamlı düzeyde farklılaşma durumunu ortaya koymak amacıyla tek yönlü varyans analizi (f testi) ile yapılmıştır. Yapılan ANOVA testi sonucu tablo 16'da ifade edilmektedir. $\mathrm{f}$ değeri 39,199 bulunmuştur. Bu sonuç 0,05 düzeyinde anlamlı bir farkın olduğunu ortaya koymuş bulunuyor. Farklılığın kaynağını anlamak için test yapmadan önce, varyans eşitliği hipotezi test edilmiştir. Levene testi sonucunda $(p<0,05)$ varyansların eşit olmadığı sonucu çıkmıştır. Bu nedenle Post-hoc testlerinden Dunnett T3 testi uygulanmıştır. Tablo 16 bu testin sonucunda, 05 anlamlılık düzeyinde; Bolu Üniversitesi'nin Sakarya Üniversitesi dışında tüm üniversitelerden farklılaştığını, Düzce Üniversitesinin tüm üniversitelerle farklılık gösterdiği, Kocaeli Üniversitesi'nin Yalova Üniversitesi dışında Yalova Üniversitesinin de Kocaeli Üniversitesi dışında tüm üniversitelerden farklılaştığını, Sakarya Üniversitesinin de Bolu dışında benzerlik gösterdiği başka üniversite olmadığı görmekteyiz.

\section{Araştırma Modeline İlişkin Bulgular}

Tablo 17. Üniversite Öğrencilerinin Sportif Tutumlar, Yaşam Kalitelerini Açıklama Gücü

\begin{tabular}{llllllllll}
\hline Model & $\mathbf{r}$ & $\mathbf{r} 2$ & $\mathbf{r 2}$ & $\mathbf{f}$ & $\mathbf{p}$ & $\begin{array}{l}\text { Std. } \\
\text { Hata }\end{array}$ & $\mathbf{B}$ & $\mathbf{t}$ & $\mathbf{p}$ \\
\hline $\begin{array}{l}\text { Sportif } \\
\text { Tutum }\end{array}$ &, $232^{\mathrm{a}}$ & 0,054 & 0,053 & 0,518697 &, $000^{\mathrm{b}}$ & 0,031 & 0,232 & 7,266 & $\mathbf{0 , 0 0 0 ^ { * }}$ \\
\hline
\end{tabular}

${ }^{*} p<0,05$ 
Üniversite öğrencilerinin sportif tutumlarının, yaşam kalitelerini açıklama gücünü ortaya koymak amaciyla basit doğrusal regresyon analizi tekniği kullanılmıştır. Analize ilişkin bulgular tablo 17 'de verilmiştir. Sportif tutumun yaşam kalitesini açıklamada bağımsız değişken olarak analize sokulması ile hesaplanan regresyon katsayısı 0,232 (R) bulunmuştur. Hesaplanan bu değere göre yaşam kalitesi varyansın yani değişkenliğin $\% 5,4$ ü sportif tutumdan kaynaklanmaktadır. Hesaplanan $\mathrm{f}$ değeri $(\mathrm{f}=52,800)$ sportif tutumun yaşam kalitesini anlamlı düzeyde açıkladığını göstermektedir $(\mathrm{p}<0,01 ; \mathrm{p}<0,05)$.

Üniversite öğrencilerinin sportif tutumlarının, yaşam kalitelerini açıklama gücü tablo 11'de verilmiştir. Tablo 11 incelendiğinde hesaplanan $t$ değeri, sportif tutumun yaşam kalitelerini anlamlı düzeyde açıkladığı göstermektedir. Kısmi korelasyon katsayısına ( $\beta$ ) bakıldığında sportif tutumun yaşam kalitesi ile 0,232 düzeyinde pozitif yönde ve anlamlı bir ilişkiye sahip olduğu bulunmuştur $(\mathrm{p}<0,01 ; \mathrm{p}<0,05)$.

\section{Tartışma ve Sonuç}

Bu çalışma farklı bölümlerde öğrenim gören üniversite öğrencilerinin spora yönelik tutumları ile yaşam kalitesi arasında bir ilişki olup olmadığını belirlemeye yönelik yapılmıştır. Üniversite öğrencilerinin sportif tutumlarının, yaşam kalitelerini açıklama gücünü ortaya koymak amacıyla yapılmış olan basit doğrusal regresyon analizi sonuçlarına göre sportif tutumun yaşam kalitesi düzeyinde pozitif yönde ve anlamlı bir ilişkiye sahip olduğu bulunmuştur $(p<0,01 ; p<0,05)$. Bu sonuç yapılmış olan bazı araştırmadaki sonuçlar ile paralellik göstermektedir.

Konu ile ilgili yapılmış olan benzer çalışmalarda Önal ve diğ. (2017) araştırmaya katılan bireylerin yaşam kalitesi ve spora yönelik tutum toplam puanları ve alt boyut puanları cinsiyet açısından incelendiğinde anlamlı farklılıklar saptanmıştır. Cinsiyet açısından yaşam kalitesi toplam puanı ve alt boyutları incelendiğinde bedensel alan alt boyutunda anlamlı bir farklılık ortaya çıkmazken; ruhsal alan, sosyal alan ve evrensel alan alt boyutlarında erkeklerin lehine anlamlı farklılıklar ortaya çıkmıştır. (Okyay ve diğ.2012) yaptıkları çalışmalarında tolumda yaşam kalitesi düzeyinin yükseltilmesinde kadınların ruhsal bozukluk belirtilerinin fark edilmesi ve sosyal destek sağlanması kadınlarda yaşam kalitesinde artışa etki edebilecek etmenler olarak 
ifade etmişlerdir. Vural ve diğ. (2010) tarafından masa başı işlerde çalışan bireyler üzerinde yapılan bir çalışmada yaşam kalitesi puanlarının erkeklerde kadınlara göre daha yüksek olduğu belirtilmiştir. Çakıroğlu (2007) yaptığı çalışmada farklı toplumlarda yaşam kalitesine etki eden sosyo-demografik özelliklerden eğitim durumunun yaşam kalitesine çok fazla etki etmediğini Türk toplumunda cinsiyetin yaşam kalitesiyle olan ilişkisinde kadınların erkeklere oranla daha fazla mutlu olduklarını belirtmiştir. Tekkanat (2008) öğretmenlik bölümünde okuyan öğrenciler üzerine yaptığı çalışmasında erkeklerin yaşam kalitesi puanlarının kadınların puanından yüksek olduğunu ortaya koymuştur. Başka bir çalışmada Acree ve diğ. (2006) yaşlı bireyler üzerinde yaptıkları çalışmasında yine erkeklerin kadınlara göre yaşam kalitesi puanlarının daha yüksek olduğu sonucuna ulaşmışlardır. Bu farklılıkların örneklem grubundan ve çevresel faktörlerin her bölgede değişiklik göstermesinden kaynaklandığı düşünülebilir. Ercan (2010) yaptı̆̆ tez çalışmasında bireylerin yaşları ilerledikçe yaşam kalitelerinde de düşüş olduğunu tespit etmiştir. Önal ve diğ.(2017) spora yönelik tutum toplam puanı ve alt boyut puanları cinsiyet değişkeni açısından incelendiğinde anlamlı farklılıklar bulunmuştur. Fiziksel gelişme alt boyutunda anlamlı bir farklılık saptanmazken; psikososyal gelişme ve zihinsel gelişme alt boyutlarında anlamlı farklılıklar ortaya çıkmışır.

Çalışmanın amaçlarından biri olan yaşam kalitesi ve spora yönelik tutum arasındaki ilişkiye bakıldığında, elde edilen veriler neticesinde yaşam kalitesi ve spora yönelik tutum arasında pozitif yönlü bir ilişki olduğu tespit edilmiştir. Bireylerin spora karşı bilişsel, duyuşsal ve davranışsal olarak bakış açıları, mevcut yaşantılarını kaliteli ve tatminkâr bir şekilde sürdürmeleri açısından önemli olduğu söylenebilir.

$\mathrm{Bu}$ çalışma farklı bölümlerde öğrenim gören üniversite öğrencilerinin spora yönelik tutumları ile yaşam kalitesi arasında bir ilişki olup olmadığını belirlemeye yönelik yapılmıştır. Çalışmada Doğu Marmara bölgesinde yer alan beş devlet Üniversitesinde (Kocaeli Üniversitesi, Sakarya Üniversitesi, Düzce Üniversitesi, Bolu Abant İzzet Baysal Üniversitesi ve Yalova Üniversitesi) öğrenim görmekte olan 933 öğrencinin spora yönelik tutumlarının cinsiyet, spor yaptıkları yıl miktarı, medeni durumları, eğitim aldıkları üniversiteler, ailenin ekonomik gelir düzeyleri, yaşam kalitesi, değişkenleri açısından incelenmiş olup spora yönelik tutum düzeyleri arasında anlamlı bir farklılık olduğu tespit edilmiştir $(p<0,05)$. 
Araştırmaya katılan öğrencilerin cinsiyet değişkenine göre ölçeklerin genelinden alınan toplam puanların ortalamalarına bakıldığında kadın öğrencilerin spora yönelik tutum puanlarının erkek öğrencilerin spora yönelik tutum puanlarından daha yüksek olduğu gözlenmiştir ( $p>0.05$ ). Alan yazında yapılan bazı çalışmalar da bu analiz sonucunu destekler şekildedir.

Yazıcı ve diğ.(2016) ile Hazar ve diğ.(2018) üniversite öğrencilerinin spora yönelik tutumları üzerine yapmış oldukları çalışmada kadın öğrencilerin erkek öğrencilere kıyasla spora yönelik daha fazla eğilimlerinin olduğu ancak bu eğilimin istatistiksel olarak anlamlı olmadığı belirtilmektedir. Atalı ve diğ. (2018) farklı fakültelerden spor ile ilgili ders alan öğrencilerin spora yönelik tutumları üzerine yapılmış olan çalışmaların da ise öğrencilerin spora yönelik tutumlarının psikososyal ve fiziksel gelişme alt boyutlarında kadın öğrencilerin puanlarının erkek öğrencilerin puanlarından zihinsel gelişme alt boyutunda ve ölçek toplam puanlarında ise erkek öğrencilerin kadın öğrencilerden daha yüksek puan aldıkları belirlenmiştir.

Bu bulgular, mevcut çalışmanın sonucu ile örtüşmemektedir. Öğrenciler arasında anlamlı farkın çıkması, kadın ve erkek öğrencilerin spora yönelik benzer eğilim göstermemesinden kaynaklanmaktadır diyebiliriz. Ayrıca, benzer çalışmalarda anlamlı farkın çıkması, yapılan çalışmaların farklı gruplar üzerinde gerçekleştirilmesinden kaynaklanmaktadır. Farklı gruplardaki bireylerin spora bakış açısının farklı olması etkilidir. Sonuç olarak yapılan birçok çalışma incelendiğinde spora yönelik tutum puanlarının erkeklerin lehine daha yüksek bulunduğu söylenilebilir ve bu bulgular yapılan bu çalışmadaki spora yönelik tutum sonuçlarını destekler niteliktedir. Fakat araştırmamızın aksine Büyükdemira, Soyer ve Türkoğlu (2018) tarafından yapılmış olan çalışmada ortaöğretim öğrencilerinin cinsiyetlerine göre beden eğitimi ve spor dersine ilişkin tutumları arasındaki farklılıklar incelendiğinde, erkek öğrencilerin kadın öğrencilere göre daha olumlu tutum gösterdikleri bulunmuştur.

Üniversite öğrencilerinin kendilerinin ve ailelerinin ekonomik gelir düzeyi değişkenine göre spora yönelik tutumlarına bakıldığında, öğrencilerin kendilerinin ve ailelerinin ekonomik gelir durumlarına göre spora yönelik tutumları arasında yapılan test sonucunda f değeri 13,998 bulunmuştur. Bu sonuç 0,05 düzeyinde anlamlı bir farkın olduğunu ortaya koymuş bulunmaktadır. Farklılığın kaynağını anlamak için test yapmadan önce, varyans eşitliği 
hipotezi test edilmiştir. Levene testi sonucunda $(p>0,05)$ varyansların eşit olduğu sonucu çıkmıştır. Bu nedenle Post-hoc testlerinden Tukey testi uygulanmıştır. Bu testin sonucunda, 05 anlamlılık düzeyinde; en düşük, düşük ve orta gelir düzeyine sahip öğrenciler arasında anlamlı bir fark olmadığı görülmüştür $(p>0,05)$. Fakat yüksek ve en yüksek gelir düzeyine sahip öğrencilerin arasında da anlamlı bir fark görülmemiştir. Buna karşın orta ve altı gelir düzeyine sahip öğrencilerin yüksek ve üzeri gelire sahip öğrencilerden sportif tutum açısından farklılaştığı görülmektedir. Yanık ve Çamlıyer, (2015) yapmış oldukları araştırmada öğrencilerin aile gelir düzeyine göre beden eğitimi dersine ilişkin tutum ölçeği puan ortalamaları incelendiğinde gruplar arasında istatistiksel olarak anlamlı bir fark görülmemiştir. Ancak gelir düzeyi azaldıkça öğrencilerin beden eğitimi dersine yönelik tutum puanı ortalamasının yükseldiği belirlenmiştir. Bu sonuç mevcut araştırmadaki sonuç ile paralellik göstermektedir. Diğer yandan üniversite öğrencileri üzerine yapılan bir araştırmada aylık aile gelir düzeyi orta seviyede olanların düşük ve yüksek olanlara göre beden eğitimi ve spora yönelik tutumlarının daha iyi düzeyde olduğu saptanmıştır (Yıldız ve ark, 2017).

Aynı çalışmada Yıldız ve ark, (2017) spor yapmayan üniversite öğrencilerinin spora yönelik tutumlarının spor yapanlardan daha yüksek olduğunu saptamıştır. Bu çalışmanın aksine Güllü ve ark, (2016) aktif spor yapanların aktif spor yapmayanlara göre spora yönelik tutumlarının anlamlı şekilde daha yüksek olduğunu tespit etmiştir. Ortaokul öğrencileri üzerine yapılan bir araştırmada raket sporu yapan öğrencilerin spora yönelik tutumları takım sporu ve diğer sporları yapanlara göre daha yüksek olduğu görülmüştür (Güllü ve ark, 2016). Doğu Marmara bölgesinde yer alan beş devlet üniversitesinde (Kocaeli Üniversitesi, Sakarya Üniversitesi, Düzce Üniversitesi, Bolu Abant İzzet Baysal Üniversitesi ve Yalova Üniversitesi) öğrenim görmekte olan 933 üniversite öğrencisinin spora dair tutumlarının yaş, eğitim düzeyi, gelir düzeyi ve gelir düzeyi memnuniyeti, sporu tek başına yeterli bir gelir olarak görme durumu, değişkenleri açısından farklılaşıp farklılaşmadığı incelenmiştir fakat değişkenler arasında anlamlı bir farklılık bulunamamıştır ( $>>0,05)$.Spora yönelik tutum yaşam kalitesini pozitif yönde anlamlı düzeyde, etkilemiştir. Yapılan araştırmada öğrencilerinin yaş değişkenine göre spora yönelik tutum puanlarına bakıldığında öğrencilerin yaşlarına göre spor yönelik tutumları arasında anlamlı bir farklılığın olmadığı görülmüştür 
( $p>0,05)$. Bu sonucu destekler nitelikte Türkmen ve ark (2016) tarafından Bartın Üniversitesi İslami İlimler Fakültesi öğrencilerine yönelik yapılan spor tutumu çalışmasında öğrencilerin yaş ile spora yönelik tutumları arasında anlamlı farklılık görülmemektedir. Tatar ve Kuru (2009) 20-40 yaş arası çalışan ve çalışmayan kadınların spor yapmalarını etkileyen bazı faktörlerin incelenmesi (Sivas il merkezi örneği) çalışmasında araştırmaya katılan kadınların spor yapmalarında yaş önemli bir faktör değildir şeklindedir. Bu çalışmalar mevcut çalışmanın sonucu ile benzerlik göstermektedir. Fakat Kangalgil ve diğ. (2006) tarafından yapılan çalışmada ise öğrencilerin yaşları büyüdükçe beden eğitimi ve spora karşı tutum puanlarının arttığı gözlenmiştir.

Sporun belirlenen hedeflerine ulaşabilmesi için öğrenciler tarafından sporun sevilmesi ve öneminin anlaşılması oldukça önemlidir. Sporun istenen hedeflerine ulaşabilmesi gençlerin spora yönelik tutumları ile yakından ilişkilidir (Başer, 2009). Spora yönelik tutumu olumlu olan birey, daha istek ve arzu ile spora yönelmekteyken, tersi durumda birey spordan uzaklaşabilmektedir. Gençlerin sahip oldukları kişisel yetenekleri ve sportif etkinlikler dâhilinde ortaya koydukları hareketler gençlerin spora karşı tutumlarını belirlemektedir. Öğrenin; daha önce jimnastik hareketi yapmamış olan bir birey bu hareketi sistemli ve hedefine uyacak bir biçimde yapamayabilecektir. Buna ek olarak gencin söz konusu hareketi ortaya koyarken sakatlanma ihtimali de mevcuttur. Bu durum bireyin diğer spor hareketlerinde jimnastik sporuna özgü hareketlerden çekinmesine, jimnastik sporuna özgü hareketleri sırasında karşılaştığı olumsuz durumları hatırlamasına ve spora karşı olumsuz tutumlar geliştirmesine sebep olmaktadır. Bu olumsuz durumlar karşısında bireyin jimnastik sporuna özgü hareketlerine ve spora karşı olumsuz tutumlar ortaya koyması olası bir neticedir (Aras, 2013). Her birey yaşadığı olumsuzluklar karşısında kendince bir savunma mekanizması geliştirir. Yaptığı sportif hareketler ile yaşayacağ bir veya birden fazla olumsuzluk da bireyin spordan uzaklaşmasına sebep olacak bir tutum geliştirmesine neden olacaktır. Spora karşı olumsuz tutumu olan öğrencinin derse karşı olan ilgisi azalmakta ve öğrenci derse girmeme yoluna bile gidebilmektedir. Öğrencilerin derse verdikleri önemin azalması da dersin işlenişini ve etkinliğini düşürmektedir. Bu açıdan bakıldığında spora karşı olan tutumun öğrenim etkinliklerinin başarılı olması konusunda önemli bir unsur olduğunu söylemek mümkündür (Çelik ve Pulur, 2011). 
Sonuç olarak, mesleki olgunlaşma ve sosyal hayata hazırlanma dönemi olarak anılan üniversite hayatı, yalnızca akademik başarıya odaklı bir yaşam süreci olarak görülmemelidir. Üniversitelerde seçmeli olan beden eğitimi dersi saatlerinin arttırılarak her bölüm ve programda zorunlu ders olarak eklenmeli böylece öğrencilerin ders ve yaşam stresinden uzaklaşmaları, deşarj olabilmeleri ve ayn zamanda yaşam kalitelerinin yükseltilerek akademik başarı düzeylerinin iyileştirilmesi amaçlanmalıdır. 


\title{
EXTENDED ABSTRACT
}

\section{Analyzing the Effect of University Students' Attitudes towards Sports on Quality of Life:Eastern Marmara Region Universities Sample \\ *}

\author{
Ülkü Çoban - Betül Bayazıt - Merve Uca \\ Yalova University, Kocaeli University, Aydın University
}

In this study, it was aimed to analyse the effect of sports-oriented attitudes of students in different programs in Eastern Marmara region universities (Kocaeli University, Düzce University, Sakarya University, Bolu Abant Izzet Baysal University, Yalova University) on quality of life level. The research was conducted on a total of 933 under graduate and associate degree students who are studying in different departments of 5 state universities in the Eastern Marmara region. In the research sample, the effect of the attitudes of the university students who made up the study group towards sport on their quality of life was analysed.

Physical education and sports are often perceived as the equivalent of physical activity habits. However, sports provide the individual's body and mental health, the formation of personality and the development of character traits, as well as the individual's knowledge, skills and ability to improve harmony with the environment.

The attitude is an important Notion of psychology. There is a general consensus that attitude as a word meaning represents the assessment of a psychological object in dimensions of self-nature, such as good-bad, harmful-beneficial, pleasant-unpleasant, and ordinary- unusual.

In view the role of university students in the formation of cultural and social norms, the importance of these students ' sporting activity habits increases. Although the effects of regular sports activities on health have been acknowledged, the relationship between attitude towards sport and quality of life has not been clearly explained. Not enough research has been done on attitudes towards sport and levels of quality of life in general. It is clear that sports activities are one of the most important tools for strengthening the communication skills and socialization of children and young people. The 
findings that reveal that sports are effective in the individual's personality development and adaptation process to society have been procured, as well as some pozitive effects have been revealed in the research. It is thought that the attitudes of university students towards sports have a positive effect on their quality of life and academic achievement by increasing their sense of quality of life.

It is thought that the attitudes of the university students towards sports have a relationship with the quality of life and that the attitude towards sports has a positive effect on the quality of life by increasing their sense of self-efficacy. Nevertheless, it is necessary to look at the main goals of all the studies done to create a sports society by increasing the number of individuals engaged in sports. In this way, there is a need to work on university students who will shed light on our future, such as whether there is a gender difference, how prone to sports activities, sports perspectives, sports habits, sports events and how they can nurture their persopnalities

Many definitions of the Notion, self, quality of life, body image have been made in the studies. Although there are little differences in the definitions, in the most general sense, the Notion of self can be defined as the person's descriptions of himself or herself. Quality of life, on the other hand, is defined as the evaluations that the person makes for these descriptions. In other words, the notion of self includes the thoughts and perceptions one has about one self, while quality of life in volves one's feelings towards one's self. Self-acceptance is a term for whether or to what extent an individual accepts the characteristics that he or she adopts as part of his or her personality as a result of realizing the aspects that he or she can not achieve to his or her ideal self. In other words, self-acceptance is whether the individual is satisfied with his or her characteristics or to what degree he or she is satisfied (Videbeck 2001). In our study, the findings of the analysis carried out to demonstrate the power of university students to express their quality of life indicate that sporting attitude explains quality of life at a significant level. $(p<0,01 ; p<0,05)$.

Consequently, university life, which is referred to as the period of professional maturation and preparation for social life, should not be seen as a life process focused solely on academic success. It is aimed to increase the academic success levels of the students by increasing hours of elective physical education lessons in universities and adding them as compulsory lessons in each department and program, thereby increasing the quality of life of students. 


\section{Kaynakça / References}

Aras, Ö. (2013). Illköğretim kurumlarn ikinci kademede öğrenim gören öğrenci ve görev yapan beden eğitimi öğretmenlerinin beden eğitimi dersine yönelik görüş ve tutumlarmın incelenmesi:Kars İli örneği. Yayımlanmamış Yüksek Lisans Tezi, Gazi Üniversitesi/Eğitim Bilimleri Enstitüsü, Ankara.

Acree, L.S., Longfors, J., Fjeldstad, A., Fjeldstad, C., Schank, B., Nickel, K.J. et al. (2006). Physical ctivity is related to quality of life in older adults. Health And Quality Of Life Outcomes, 2006;4:37

Ajzen, I. (2001). Nature and operation of attitudes. Annual Review Of Psychology, 52(1), 27-58.

Atalı,L., Uzuner, M. L. (2018). Farklı fakültelerden spor ile ilgili ders alan öğrencilerin spora yönelik tutumlarını incelenmesi:Kocaeli Üniversitesi örneği. Examınatıon Of The Attıtudes Of The Students Who Ar Related To Sports From Different Faculties Towards Sport (Kocaeli University Example)

Başer,S. A. (2009). Öğretmen niteliklerinin beden eğitimi dersi alan öğrencilerin bu derse karşı olan tutumlarına etkisi. Yayımlanmamış Yüksek Lisans Tezi. Abant İzzet Baysal Üniversitesi/Sosyal Bilimler Enstitüsü, Bolu.

Başaran, S., Güzel, R., Sarpel, T., (2005). Yaşam kalitesi ve sağlık sonuçlarını değerlendirme ölçütleri. Romatizma. 20,1:55-63s

Büyükdemir, D., Soyer,F., ve Türkoğlu,Ç. (2008). Farklı ortaöğretim programlarında öğrenim gören öğrencilerin beden eğitimi ve spor dersine ilişkin tutumları. E R P A International Congresses on Education,28 Haziran-1 Temmuz İstanbul, 417.

Çakıroğlu, A. (2007). Relationship between quality of life and happiness in Turkey. Yüksek Lisans Tezi. Orta Doğu Teknik Üniversitesi. Ankara.

Çelik, Z., ve Pulur, A. (2011).Ortaöğretim öğrencilerinin beden eğitimi ve spora ilişkin tutumları.VAN/YYü Eğitim Fakültesi Dergisi, Özel Sayısı, 115-121.

Çetin, M. (2007).Ortaöğretim öğrencilerinin beden eğitimi ve spora ilişkin tutumlarmın karşılaştırılması: Kırşehir Il Örneği. Yayımlanmamış Yüksek Lisans Tezi. Gazi Üniversitesi Eğitim Bilimleri Enstitüsü, Beden Eğitimi ve Spor Öğretmenliği Bilim Dalı, Ankara.

Ercan, N. (2010). Huzurevinde yaşayan yaşllarm yaşam kalitesi ve yaşam kalitesini etkileyen faktörler. Halk Sağlığı Hemşireliği programı. Yüksek Lisans Tezi. Sağlık Bilimleri Enstitüsü. Hacettepe Üniversitesi. Ankara.

Fidaner, H., Fidaner, C., Elbi, H., Eser, E., Eser , S.Y , Göker, E.(1999). Yaşam kalitesinin ölçülmesi. Whoqol- 100 ve Whoqol- Bref. 3p Dergisi, Yaşam Kalitesi Özel Sayısı 7, 5-13. 
Gerrig, R. J.,Zimbardo, P. G. ve Sart, G. (2013).Psikoloji ve yaşam: Psikolojiye giriş. Nobel Yayincilik.

Güllü, M., Güçlü, M. ve Arslan, C.(2009). Ortaöğretim öğrencilerinin beden eğitimi dersine ilişkin tutumlarının incelenmesi. E-Journal of New World Sciences Academy, 4(4),273-278.

Güllü, M., Cengiz, Ş.Ş., Öztaşyonar, Y. (2016). Ortaokul öğrencilerin beden eğitimi ve spor dersine ilişkin tutumlarının bazı değişkenlere göre incelenmesi: Şanlıurfa İli örneği. Gaziantep Üniversitesi Spor Bilimleri Dergisi. 1(2). 49-61.

Hazar, K., Kaya, M., Çelikbilek, S., ve Afyon, Y. A. (2018). Seçmeli beden eğitimi ve spor derslerini tercih eden üniversite öğrencilerinde beden algısı ve spor derslerine katılım nedenlerinin araştırılması.Beden Ĕ̆itimi ve Spor Bilimleri Dergisi, 12(1), 65-72

Karasar, N. (2009). Bilimsel araştırma yöntemleri.Ankara:Nobel Yayınları.

Kangalgil, M., Hünük, D., Demirhan, G. (2006).Illköğretim, lise ve üniversite öğrencilerinin beden eğitimi ve spora ilişkin tutumlarının karşılaştııılması.Hacettepe Spor Bilimleri Dergisi, 17(2), 48-57.

Okyay, P. Atasoylu, G. Önde, M. Dereboy, Ç. Beşer, E. (2012).Kadınlarda yaşam kalitesi anksiyete ve depresyon belirtilerinin varlığında nasıl etkileniyor kesitsel bir alan çalışması. TürkPsikiyatri Dergisi, 23(3), 178-188.

Önal, L., Yılmaz, H., Kaldırımcı, M., ve Ağduman, F. (2017). Atatürk Üniversitesi öğrencilerinin spora karşı tutumları ile yaşam kaliteleri arasındaki ilişkinin incelenmesi. Muş Alparslan Üniversitesi Uluslararası Spor Bilimleri Dergisi, cilt.1, ss.26-34, 2017

Şentürk, E. Ş. (2002).Spora yönelik tutum ölçeği: Geliştirilmesi, geçerliliği ve güvenirliği. CBÜ Beden Eğitimi Ve Spor Bilimleri Dergisi, 7(2), 8-18.

Şişko, M., Demirhan, G.(2014). İlköğretim okulları ve liselerde öğrenim gören kız ve erkek öğrencilerin beden eğitimi spor dersine ilişkin tutumları, Hacettepe Üniversitesi Eğitim Fakültesi Dergisi, 23, 205-210.

Taşğın, Ö. ve Tekin, M. (2009).Çeşitli değişkenlere göre ilköğretim ve orta öğretim kurumlarında öğrenim gören öğrencilerin beden eğitimi ve spor dersine ilişkin tutum ve görüşleri. Kastamonu Eğitim Dergisi, 17(2), 457-466.

Tatar, N. Ve Kuru, M. (2009).Açıklamalı yöntemlere karşı araştırmaya dayalı öğrenme yaklaşım: İlköğretim öğrencilerinin fen bilgisi dersine yönelik tutumlarına etkileri. Pamukkale Üniversitesi Ĕ̆itim Fakültesi Dergisi, 25(25), 153-165. 
Tekkanat, Ç. (2008).Öğretmenlik bölümünde okuyan öğrencilerde yaşam kalitesi ve fiziksel aktivite düzeyleri. Pamukkale Üniversitesi. Sağlık Bilimleri Enstitüsü. Yüksek Lisans Tezi. Denizli.

Türkmen, M., Abdurahimoğlu, Y., Varol, S., Gökdağ, M.(2016). İslami İlimler Fakültesi öğrencilerinin spora yönelik tutumlarının incelenmesi: Bartın Üniversitesi Örneği. International Journal Of Contemporary Educational Studies (Intjces),2(1), 48-59

Vural, Ö. Eler, S. Atalay Güzel, N. (2010).Masa başı çalışanlarda fiziksel aktivite düzeyi ve yaşam kalitesi ilişkisi. Spormetre Beden Eğitimi Ve Spor Bilimleri Dergisi. VIII(2), 69- 75.

Yanık, M., Çamlıyer, H. (2015). Ortaöğretim 9. sınıf öğrencilerinin beden eğitimi ve spora ilişkin tutumları ile okula yabancılaşma düzeyleri arasındaki ilişkinin belirlenmesi.Uluslararası Spor, Egzersiz Ve Antrenman Bilimi Dergisi, 1(1), 9-19.

Yazıcı, N. A., Kalkavan, A., ve Özdilek, Ç. (2016). Üniversite öğrencilerinin beden eğitimi ve spor öğretimi dersine ilişkin tutumlarının bazı değişkenler açısından incelenmesi.International Journal Of Science Culture And Sport (Intjscs), 4(2), 404-411.

Yetim, A. (2016). Sporun tanımı, alanı, amaç ve fonksiyonları. Sporda etkili iletişim. Ankara:Spor Kitabevi.

Yıldız, A. B., Yılmaz, B., ve Arı, Ç. (2017).Üniversite öğrencilerinin spora yönelik tutumlarının incelenmesi. Ankara Yıldırım Beyazıt Üniversitesi Örneği.Muş Alparslan Üniversitesi Uluslararası Spor Bilimleri Dergisi, 1(1), 3545.

\section{Kaynakça Bilgisi / Citation Information}

Çoban, Ü., Bayazıt, B. ve Uca, M. (2020).Üniversite öğrencilerinin spora yönelik tutumlarının yaşam kalitesi, düzeylerine etkisinin incelenmesi:Doğu Marmara Bölgesi üniversiteleri örneği. OPUSUluslararası Toplum Araştırmaları Dergisi, 15(26),4362-4385. DOI: 10.26466-/opus.665339 